\title{
HYMENOPTERA COLLECTED NEAR BOSTON, MASS., WITH DESCRIPTION OF A VARIETY OF BOMBUS AFFINIS.
}

\section{By J. Bequaert,}

American Museum of Natural History, New York City.

While collecting Hymenoptera at Forest Hills, Mass., and other localities in the vicinity of Boston, I have taken on two occasions a bumble-bee, which from its aberrant coloration could not be properly named with Franklin's "Bombidæ of the New World." I have been permitted to examine similarly colored Bombus, taken some years previous by Professor Wheeler at Forest Hills and by Mr. J. E. Smith at Sherborn, Mass. It was finally recognized that all these specimens belong to a striking color-variant of Bombus affinis, which it is the purpose of this note to describe and name. I have used this opportunity to present an account of the Bombidx of the neighborhood of Boston and to record some other interesting Hymenoptera of that region.

I am greatly indebted to Prof. Wm. M. Wheeler, Messrs. N. Banks, Wm. T. Davis, C. W. Johnson, E. J. Smith, C. Schaeffer, and Dr. F. E. Lutz, who have kindly allowed me to examine material in their possession or care and to use valuable information.

Bombus affinis var. novæ-angliæ var. nov.

Known in the worker and male phases, which are colored much the same. One or more of the abdominal segments behind the second are covered entirely or to a large extent with ferruginous pile (in the brightest specimens very near Ridgway's vinaceousrufous). Coloration otherwise as in typical affinis; in most of the specimens the usual reddish tinge of the yellow pile on the middle portion of the second tergite is rather faint or faded, which, moreover, is often the case with typical affinis too.

The structural characters show no differences with those of typical affinis; this is especially true for the shape of the male genitalia, which I have carefully compared with those of the typical form.

The specimens examined do not differ in size from typical affinis; total length of the worker: 12 to $14 \mathrm{~mm}$.; of the male: 16 to $17 \mathrm{~mm}$. 
Type locality: Forest Hills, Mass.; the holotype, a male taken by Prof. Wm. M. Wheeler, is deposited at the Museum of Comparative Zoölogy, Cambridge. Tre allotype, a worker from the same locality, is in the American Museum of Natural History. Also known from Sherborn, Mass., and Brooklyn, N. Y.

The extent of ferruginous pile on segments 3 to 6 is variable, the following being the combinations observed:

1. Ferruginous pile covering the major part of the fourth tergite; the extreme sides of this tergite and the whole of segments $3,5,6$, and 7 being black: one worker from Forest Hills, August 3, 1911 (Wm. M. Wheeler Coll.; allotype); two males from Sherborn, August 30 and September 8, 1913 (E. J. Smith Coll.).

2. Ferruginous pile covering the whole of tergite 4 and extending over the apical margin of tergite 3: two males from Forest Hills, June, 1911 (holotype of var. novæ-angliæ) and August 18, 1911 (Wm. M. Wheeler Coll.).

3. Ferruginous pile covering the entire fourth tergite; also the greater part of tergite 5, though with some admixture of black hair; tergite 6 with a few rufous hairs in the black pile at the base in the center: one male taken at Forest Hills, visiting the flowers of Lythrum Salicaria, August 12, 1919.

4. Tergites 4, 5, and 6 covered with ferruginous pile, except at the extreme sides and in the middle along the apical margin, where the pile is black: one male from Brooklyn, N. Y., July, 1915 (F. M. Schott Coll.).

5. Ferruginous pile very bright, covering the entire fourth tergite, tergite 3 except for a median patch of black hair near the base, and the basal part of tergite 5: one worker taken in the Arnold Arboretum at Forest Hills, collecting pollen of a cultivated variety of Viburnum, August 3, 1919. This very brightly colored specimen mimics to a certain degree Bombus ternarius Say.

It is not without some hesitation that I propose a varietal name for this curious color-variant of Bombus affinis. It has been the great merit of Franklin to elucidate the structural characters of the North American Bombidæ; and, while carefully recording the color-variants of each species, this author has wisely refrained from applying names to them. Indeed, it will be a lengthy process for future students to decide which of the many color forms of bumblebees are mere freak specimens, and which others represents racial 
differences due either to somatic and environmental influences or to germinal modifying factors. There is, I believe, ample justification for giving such fixed races a nomenclatural standing, as has been the common practice for recent years. Moreover, European students have profusely named the color forms of the palearctic bumble-bees, and, with increasing interest in the study of distributional problems, a similar course will undoubtedly be adopted for the nearctic species.

In the case of B. affinis var. novce-anglice there is every reason to believe that it is not based on freak specimens, but represents a peculiar race, which, having been repeatedly collected, must not be a great rarity in the vicinity of Boston and perhaps in some other localities. Furthermore, Bombus affinis varies, as a rule, but little in its coloration, since Franklin, in his Monograph, does not mention a single color-variant and even notes that "this species is very constant in its character, a remarkable fact when the extreme variability of a large proportion of the species of the Terrestris group is considered." I have examined over 150 specimens of B. affinis from various localities in the states of New York, New Jersey, Pennsylvania, New Hampshire, Massachusetts and North Carolina, and, with the exception of the specimens described above, have only found one aberrant male. This male, collected at Woodbury, N. Y., September 21, 1910, and belonging to the American Museum of Natural History, shows a faint indication of a transverse patch of ferruginous pile in the center and near the base of the fourth tergite; the specimen is otherwise quite normal, but is evidently a transition toward the var. novo-anglice.

Since this paper was sent to the printer, I have been able to examine several specimens of $B$. centralis Cresson and its var. juxtus Cresson, from Colorado, in the collection of the American Museum of Natural History. Such of these specimens as agree best with the description of juxtus Cresson, are very similar in coloration to the brightest individuals of $B$. affinis var. novoanglioe. B. centralis and B. juxtus are, however, at once separated from $B$. affinis by their much longer oculo-malar space and by their having yellow pile on face and occiput. Titus ${ }^{2}$ has recorded $B$. juxtus from Woods Hole, Mass.; but, as Franklin has pointed out,

1 Trans. Amer. Ent. Soc., 38, 1913, p. 280.

2 Canadian Entomol., vol. 34, pp. 39 and 43 (1902). 
this identification was undoubtedly erroneous. It seems very probable that these Woods Hole specimens belonged to $B$. affinis var. novo-anglioe.

In drawing up the following list of the Bombidæ known to occur within a radius of twenty miles from Boston, $I$ have perused, besides my own data, collected during the summer of 1919, information kindly given to me by Prof. Wm. M. Wheeler and Messrs. N. Banks, C. W. Johnson and E. J. Smith.

Bombus terricola Kirby. This is perhaps the most common species of bumble-bee at Forest Hills; also at Auburndale (C. W. Johnson Coll.) and Sherborn (E. J. Smith Coll.).

Bombus affinis Cresson. The typical form is common at Forest Hills where it visits, among others, the flowers of Ceanothus americanus; also at Auburndale and Dedham (C. W. Johnson Coll.); Sherborn (E. J. Smith Coll.).

Bombus bimaculatus Cresson. Common at Forest Hills; also at Cohasset (C. W. Johnson Coll.) and Sherborn (E. J. Smith Coll.).

Bombus impatiens Cresson. Forest Hills; also Auburndale, Dedham, Brookline, and Cohasset (C. W. Johnson Coll.); Sherborn (E. J. Smith Coll.).

Bombus ternarius Say. Mr. E. J. Smith, who has taken a few workers of this species at Sherborn, believes that it is very rare near Boston. Professor Wheeler informs me that in many years collecting he has never seen it at Forest Hills, though he has commonly taken it at Colebrook, Conn.

Bombus perplexus Cresson. Wollaston (Mus. Comp. Zoöl.); Auburndale and Arlington (C. W. Johnson Coll.); Sherborn (E. J. Smith Coll.).

Bombus vagans Smith. Forest Hills; also from Auburndale, Dedham, and Boston (C. W. Johnson Coll.); Sherborn (E. J. Smith Coll.).

Bombus fervidus Fabricius. This is a common species at Forest Hills; also at Auburndale and Cohasset (C. W. Johnson Coll.); Sherborn (E. J. Smith Coll.).

Bombus americanorum (Fabricius)=Bombus pennsylvanicus Franklin. Rather scarce near Boston; I have taken it at Lexington and Mr. E. J. Smith has it from Sherborn.

Bombus separatus Cresson. Sherborn (E. J. Smith Coll.).

Mr. E. J. Smith informs me that he has also seen a female of $B$. 
auricomus (Robertson), which, according to its label, was taken near Boston many years ago. Neither he nor Professor Wheeler has ever taken that species there, and no Boston specimens are contained in the collections of the Boston Natural History Society and of the Museum of Comparative Zoölogy.

Psithyrus laboriosus (Fabricius). Five males were taken at Forest Hills, about the middle of August, and one female in the Stony Brook Reservation at flowers of Cephalanthus occidentalis, July 21; also at Auburndale and Brookline (C. W. Johnson Coll.); Sherborn (E. J. Smith Coll.).

Psithyrus ashtoni (Cresson). Auburndale and Brookline (C. W. Johnson Coll.); Cambridge (S. Henshaw Coll.); Sherborn (E. J. Smith Coll.).

It is interesting to compare this list with other local faunas farther north and south. At Waldoboro, on the coast of southern Maine, Lovell ${ }^{1}$ did not find Bombus impatiens, B. americanorum and $B$. affinis, three species which are rather abundant in the Transition Zone. On the other hand, two forms which are rather Canadian or Boreal, B. borealis Kirby and B. ternarius Say, are still to be found in southern Maine, while borealis has never been seen near Boston and ternarius is very rare there. Otherwise the faunas of these two localities are very similar.

From my own collecting experience and from what $I$ have seen in other collections, the bumble-bee fauna of the immediate vicinity of New York City differs mainly from that of Boston in the scarcity of $B$. terricola and the absence of B. ternarius, though both these species are commonly found in the Catskills. B. ternarius has never been taken near New York City; the nearest locality for that species is Lake Marcia, Sussex County, N. J., where it was collected by Dr. F. E. Lutz. ${ }^{2}$ As to B. terricola, there are no New York specimens in my own collection, nor in that of Mr. Wm. T. Davis; I find, however, in the Brooklyn Institute of Arts and Sciences two males from Essex Fells, Essex County, N. J. (A. S. Nicolay Coll.) and, in the American Museum of Natural History, two further specimens labeled "Astoria, Long Island." Two species of the Austral Zone, B. fraternus (Smith) and B. auricomus

1 J. H. Lovell. The Bumble-bees of Southern Maine. Ent. News, 18, 1907, pp. 195-200.

2 Bull. Amer. Mus. Nat. Hist., 35, 1916, p. 514. The specimen recorded as B. ternarius from Staten Island in Smith's New Jersey List, is a worker of $B$. fervidus, though it bears a label in the late Dr. Ashmead's handwriting "B. ternarius Say." 
(Robertson), though often seen in southern New Jersey, apparently do not reach New York City.

The vicinity of Boston thus seems to be in some way the meeting ground of certain Boreal and Austral elements, while forms of the Transition Zone constitute the bulk of the local fauna. This may be one of the reasons why the insect fauna of that region contains such a variety of species. Though I was able to devote to collecting only a few odd hours during two of the last summer months, I have to my great surprise taken there many unusual Hymenoptera, among them certain species which I had not seen before in the northeastern states. It will, I believe, be interesting to put on record some of my captures.

Pachymenes symmorphus (Saussure). Two females were taken in the Arnold Arboretum at Forest Hills, July 5. This wasp has been placed by H. de Saussure in the genus Nortonia. I have shown elsewhere ${ }^{1}$ that Nortonia may best be restricted to the species with a transverse raised suture on the first abdominal tergite; whereas such species as the nearctic N. symmorpha Saussure and $N$. tolteca Saussure, in which there is no raised suture on tergite one, cannot in my opinion be generically separated from Pachymenes. I have also P. symmorphus from Greenwood Lake, N. Y., 우 , August 20, 1916; White Plains, N. Y., $\sigma^{\top}$, at flowers of Ceanothus americanus, June 29, 1918; Stowe, Lamoille County, Vt. (E. L. Bell Coll.). Mr. Wm. T. Davis has taken a o at Ramsey, N. J., July 19, 1908, and a $\sigma^{7}$ at Cabin John Run, Md., June 17, 1910.

Ancistrocerus unifasciatus (Saussure). One female at Lexington, July 27, 1919, and another at Forest Hills in June.

Anacrabro ocellatus Packard. This was very common at Forest Hills in the latter half of July, visiting Ceanothus americanus; I have also taken it at Lexington on Spircea salicifolia, July 27.

Euspongus bipunctatus (Say) $=$ Paramellinus bipunctatus Rohwer. Forest Hills, August 3, 1919; one female running about on leaves of pickerel weed in the Arnold Arboretum.

Anthophora walshii Cresson. One female sucking honey at flowers of Ballota nigra, Forest Hills, July 27, 1919. I saw a male, which I was unable to capture, at the flowers of Pontederia cordata, Forest Hills. Mr. C. W. Johnson informs me that the collection

\footnotetext{
1 Bull. Amer. Mus. Nat. Hist., 39, 1918, p. 93.
} 
of the Boston Society of Natural History contains further specimens of this species as follows: Woods Hole, Mass., 으, July 25, 1903 (C. W. Johnson Coll.); Manomet, Mass., ơ, July 17, 1904, and Falmouth, Mass., $\varnothing^{\nearrow}$, July 8, 1912 (Dr. J. A. Cushman Coll.). In these two males, the terminal joint of the middle tarsi bears the lateral patches of black pubescence characteristic of this species; furthermore, there are at the base of the clypeus two black spots narrowly connected in the middle. These points, together with the white tegumentary bands of the abdomen, make the species easy to recognize. So far as I have been able to discover, this beautiful insect, originally described from Illinois, has also been recorded from Wisconsin, Nebraska and central Texas. At Carlinville, Ill., Robertson found it sucking nectar on several flowers, among them Lespedeza reticulata, while the females gathered pollen exclusively from Cassia Chamocrista. ${ }^{1}$ In Nebraska, it was taken at the flowers of a Salvia, and Graenicher records it from Rudbeckia hirta in Wisconsin.

Xenoglossa pruinosa (Say). This handsome species is a common visitor of the flowers of cultivated squash at Forest Hills, between 6 and 8 a. m.; the flowers close by 9 a. m., but the males can often be found during the day, sleeping inside the corolla.

Dianthidium notatum (Latreille). This is fairly common in the first half of August at Forest Hills, on flowers of Lespedeza hirta and L. frutescens, which are visited by both sexes. I have also taken it at the Blue Hills Reservation, on Baptisia tinctoria.

Halictoides novæ-angliæ Robertson. Many males were seen at the flowers of Pontederia cordata in the Arnold Arboretum, Forest Hills, from July 8 to August 15; the females are much scarcer and appear later, the first being taken July 24.

Perdita octomaculata (Say). At Forest Hills this little bee was seen nesting in the sandy soil of a vacant city lot; on August 10, the two sexes were found in numbers mating within the flowerheads of Cichorium Intybus; the female also visits Solidago rugosa.

Epeoloides pilosulus (Cresson). One male at the Blue Hills Reservation, on flowers of Apocynum androscmifolium. Epeoloides nearcticus Ducke, ${ }^{2}$ described from Pennsylvania, is in my opinion a synonym of pilosulus.

1 Botanical Gazette, 25, 1898, p. 230; and 28, 1899, p. 36.

2 Rev. d'Ent. Caen, 27, 1909, p. 39. 

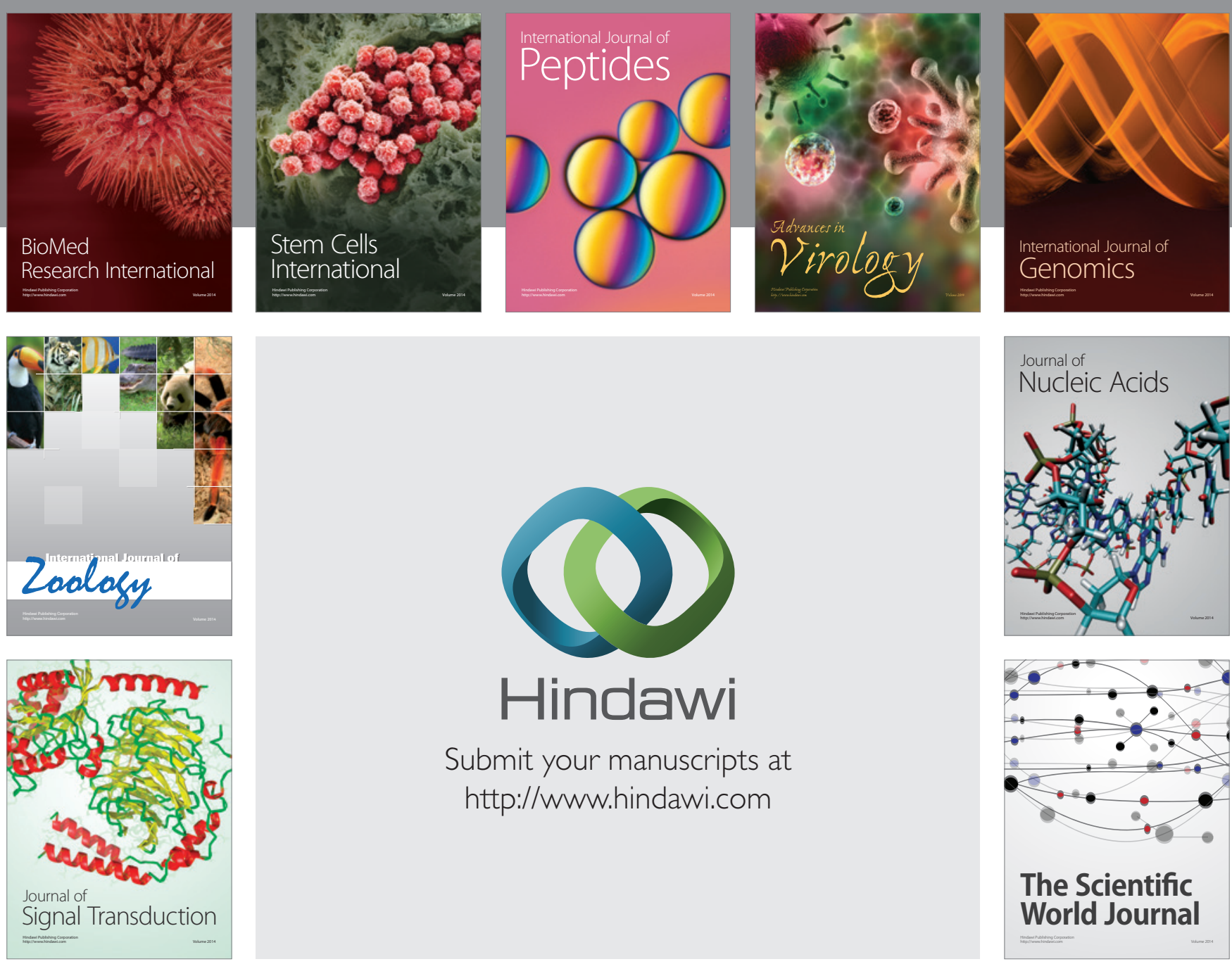

Submit your manuscripts at

http://www.hindawi.com
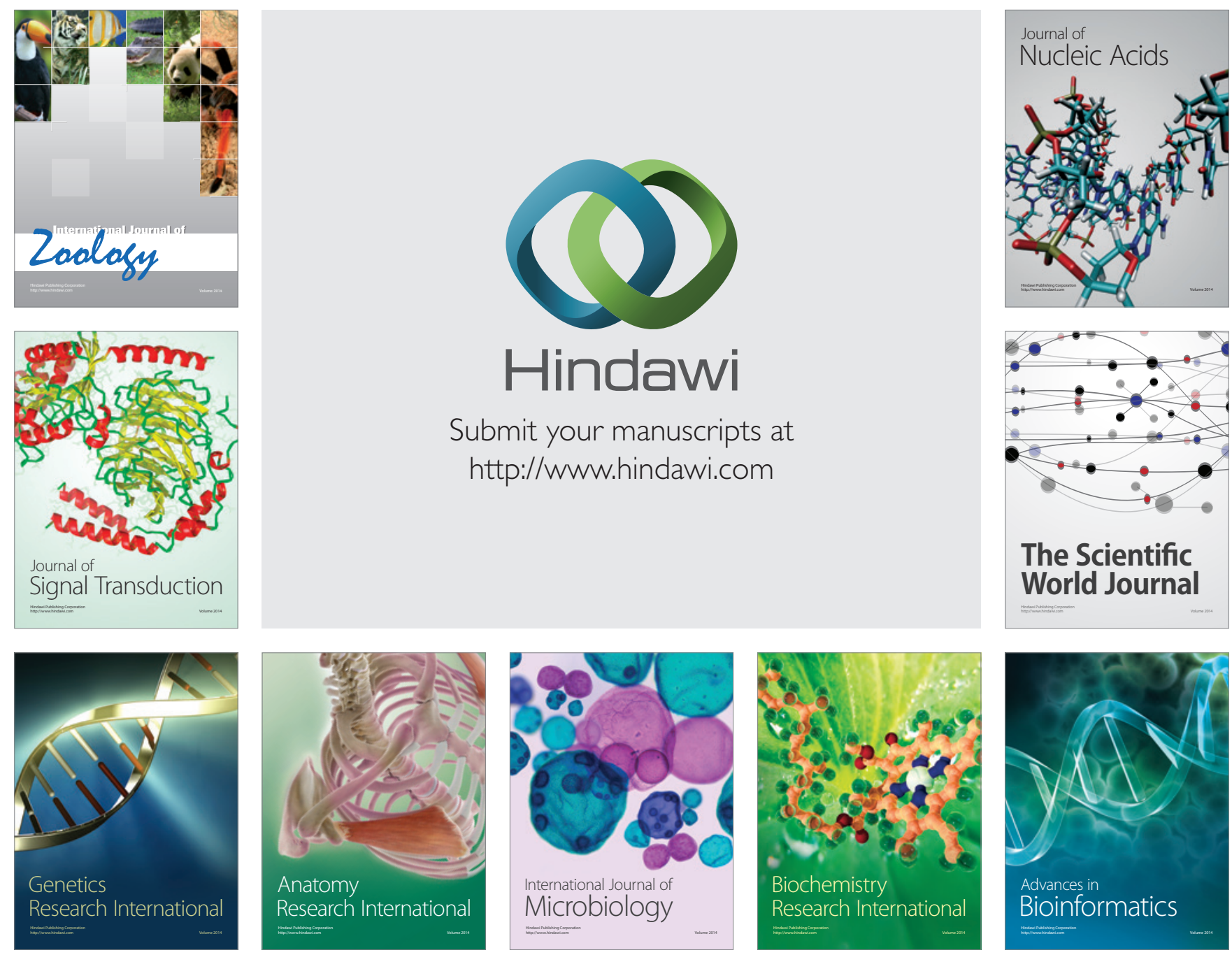

The Scientific World Journal
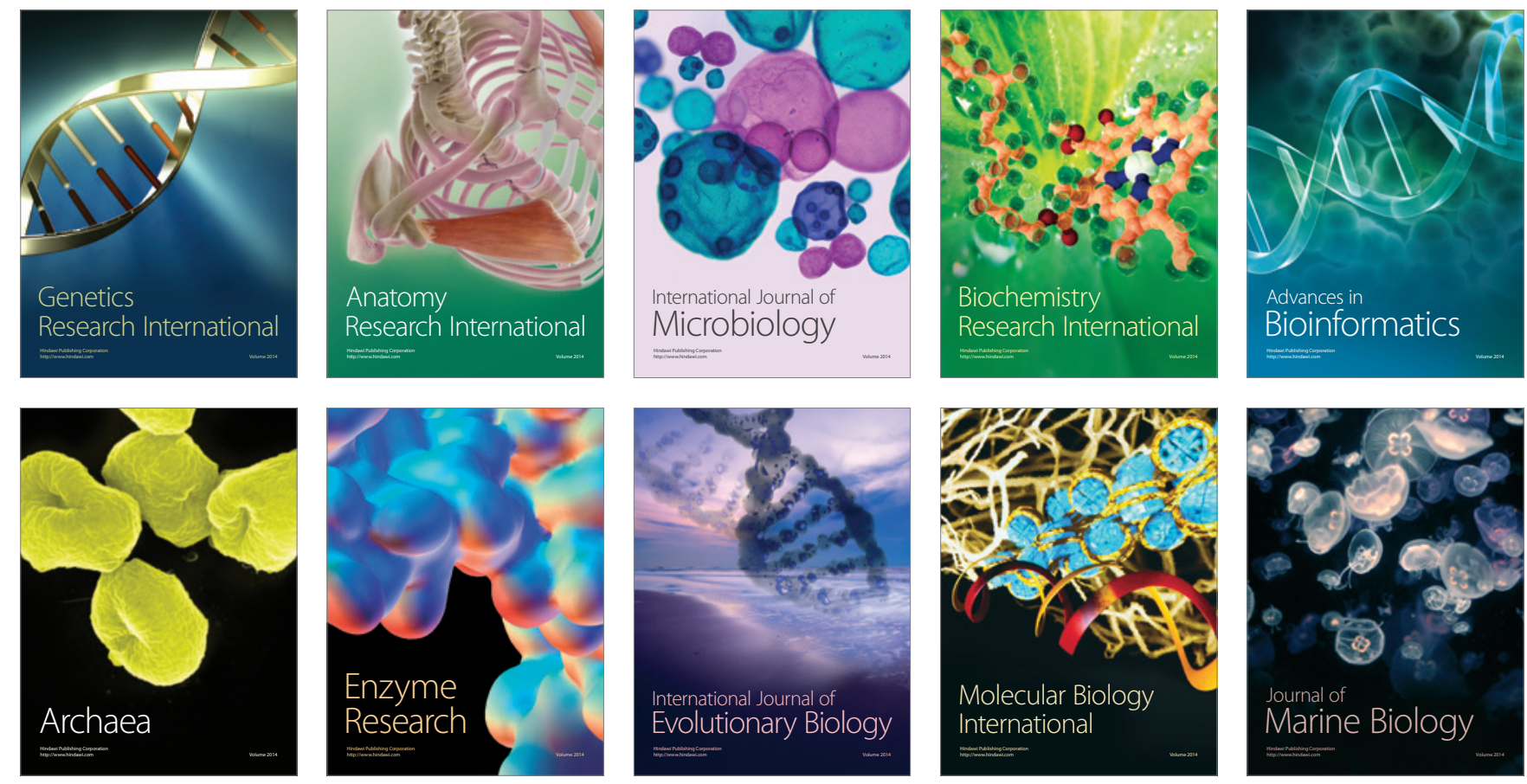